\title{
A educação a distância, a internet e a educação formal
}

\author{
Nilton Bahlis dos Santos*
}

Resumo Os computadores e a Internet aos poucos deixaram de ser objetos estranhos nas escolas e no mundo da educação. As novas tecnologias de informação e comunicação, lentamente, vão se integrando à atividade educativa. Mas elas ainda são basicamente usadas como um instrumento, um "apoio" que se acrescenta à atividade de educação que segue seu curso da mesma maneira que antes, dentro de uma visão e dinâmica bastante tradicionais. Entretanto, os processos e as práticas que elas induzem têm dinâmicas contraditórias com a natureza das atividades tradicionais da educação. Apontamos neste artigo as transformações que a Internet e as novas tecnologias de informação trazem para a educação, apresentando, em linhas gerais, algumas características das principais dinâmicas e processos que elas impulsionam. Características que mostram que suas conseqüências são muito mais radicais do que podem parecer à primeira vista e que colocam a educação, como nós a conhecemos, de cabeça para baixo.

Palavras-chave educação à distância, educação, informação, internet, complexidade, novas tecnologias, sistemas complexos

\begin{abstract}
Computers and Internet gradually become familiar objects at school and in the education field. New communication technologies slowly become part of the educational activity. But they are basically used as "support", something added to an educational practice that maintains its traditional dynamics and perspective. On the other hand, the processes and practices they induce contradict the nature of the traditional activities of education. What we will do in this article is to point out the kind of transformation Internet and new information technologies bring to education, as well as to briefly introduce some of the main characteristics that demonstrate that these dynamics and processes have consequences which are in fact much more radical than it may seem at first sight.
\end{abstract}

Keywords education, information, internet, complexity, new technologies, complex systems

\section{Introdução}

A educação a distância ${ }^{1}$ (EAD) é hoje um tema recorrente em conversas da vida privada, em organismos de planejamento e nos meios de comunicação. Grandes investimentos começam a

\footnotetext{
* Nilton Bahlis dos Santos é Doutor em Ciência da Informação (PPGCI- UFRJ) e Coordenador do Clube do Futuro e Consultor da RITS - Rede de Informações para o Terceiro Setor.
} 
serem canalizados para atividades de educação utilizando a Internet. No entanto, com exceção de algumas poucas e localizadas experiências de sucesso até o momento a EAD ainda não decolou.

Apesar disto, os computadores e a Internet aos poucos vão deixando de ser objetos estranhos nas escolas e no mundo da educação. As novas tecnologias de comunicação, lentamente, vão se integrando à atividade educativa. Mas em geral, elas são usadas basicamente como apoio, isto é, como mais um instrumento, que colabora e se acrescenta à atividade de educação que segue seu curso, da mesma forma, dentro de uma visão e dinâmica bastante tradicional.

O problema consiste em que as novas tecnologias são usadas para fazer as mesmas coisas que já vinham sendo feitas até aqui, enquanto os processos e as práticas que elas induzem, e das quais se alimentam, têm dinâmicas contraditórias com a natureza das atividades tradicionais da educação.

Quando se discute essa questão nos espaços de educação formal, nas escolas e na academia, ouvimos freqüentemente a questão de que devemos pensar "como incorporar a Internet na prática das escolas?" Normalmente quando se dirigem a mim com esta questão, eu respondo que o problema que temos não é exatamente este, mas talvez o contrário. O problema consiste em "como incorporar a escola à Internet".

O que faremos neste artigo é apontar o tipo de transformações que a Internet e as novas tecnologias de informação trazem para a educação, assim como apresentar, em linhas gerais, algumas características das principais dinâmicas e processos que elas impulsionam. Características que tornam evidente que esses processos e dinâmicas têm conseqüências muito mais radicais do que podem parecer à primeira vista e que colocam a educação, como nós a conhecemos, de cabeça para baixo.

\section{Uma transformação radical na cognição e agencia de nossa espécie}

O impacto das novas tecnologias na vida cotidiana e na sociedade é cada vez mais evidente e só passa despercebido para uns poucos renitentes que esperam assim fugir aos temores do desconhecido desta nova aventura. Mas mesmo entre os que reconhecem a sua importância, em geral sua observação se restringe às características quantitativas do processo em curso (o número de pessoas e máquinas envolvidas, a ampliação da abrangência de suas atividades, seu caráter global, os valores econômicos envolvidos, etc.), do que pelas características e dinâmicas específicas que estas novas tecnologias implementam ao nível de nosso processo cognitivo e da própria prática educativa.

$\mathrm{O}$ radicalismo da transformação em curso $^{2}$ está associado às características gerativas, particulares das tecnologias que estão sendo construídas. ${ }^{3}$ Nossa opinião é que, como a escrita (e

\footnotetext{
${ }^{1}$ Educação a distância não é exatamente um bom termo para caracterizar o tipo de prática educativa que vamos vivenciar com as novas tecnologias e com a Internet. Quanto mais não seja, porque a "distância" inexiste na Internet, como observaremos mais adiante. Porém, como este termo é correntemente utilizado para caracterizar as experiências educativas que utilizam as novas tecnologias, nós o usaremos neste artigo em benefício da comunicação com o leitor habituado a sua utilização.

2،A revolução informacional seria em realidade muito pouco se não implicasse por si só, por um lado, em uma revolução comunicativa - como em geral é assumida -; mas também, por outro, em uma radical transformação na
} 
em particular a imprensa) está no centro de um processo que gerou o que podemos caracterizar como a "Ordem do Livro", as novas tecnologias de informação e em particular a Internet estão gerando o que podemos chamar de "Ordem da Web". A transformação na prática educativa, a que nos referimos neste artigo, é apenas um dos aspectos de uma transformação mais geral que envolve processos cognitivos, aparatos de cultura, dispositivos de interação, suportes técnicos, estruturas comunicativas, enfim, que envolve um conjunto de dinâmicas específicas, em profunda relação e sincronia com as características de tecnologias determinadas. Apresentaremos a seguir o que consideramos que sejam as características particulares destas diferentes "ordens" e sua relação com a educação.

\section{A educação formal e a ordem do livro}

A comunicação oral, a escrita e a impressa podem ser entendidas como relacionadas a fases de um processo determinado de especialização pelo qual passou o aparato cognitivo da espécie humana. Se na comunicação oral (a comunicação "cara a cara") o fluxo de informações ocorre por todos os lados e em todos as direções (utilizando todas as formas de "sensores", sensações e sentidos), com a escrita inicia-se um processo de privilégio, de ordenamento e valoração destes dispositivos. A escrita, que amplia no tempo e no espaço a possibilidade de comunicação, por outro lado elimina vários dos mecanismos particulares usados na comunicação "cara a cara", como o olfato, os gestos, os sons, o tato e a maior parte da visão, entre muitos outros. Mas devido à possibilidade restrita de circulação da informação, mantém-se ainda uma certa proximidade do contexto original.

Com a imprensa e a multidão de cópias que ela viabiliza o contexto começa a se distanciar e perder sua capacidade de constrição, permitindo uma espécie de "relaxamento" e diluição do contexto original e a reconstrução e criação de um novo contexto por parte do leitor. Se para a comunicação na área literária isto não é um problema, porque a intenção de provocar uma ação determinada e específica é objetivo secundário, este não é o caso da comunicação para fins utilitários (científica e tecnológica). Os objetivos produtivistas levam a uma radicalização da priorização e "ordenamento" dos dispositivos cognitivos da espécie, ${ }^{4}$ tanto do ponto de vista das prioridades colocadas por estes objetivos, quanto pela racionalidade de sua utilização devido à natureza do "canal". A narrativa (o encadeamento das informações em uma história), que

cognição social e na própria estrutura da agencia que é própria de nossa espécie” (NAVARRO, 2002).

${ }^{3}$ Levy ressalta o fato de se tratarem de "tecnologias de inteligência" (LEVY, 1993). Navarro fala das características “originárias" da Internet, como tecnologia que vai além dos objetivos que se propunha: "A Internet - assim como a escrita - foi e segue sendo o que poderíamos chamar de uma invenção tecnológica originaria: um artefato que, em lugar de ser uma resposta mais o menos previsível a uma demanda social preexistente, gera um espaço de possibilidades inteiramente novo, no qual as demandas sociais devem ser recriadas - mais que traduzidas. O telefone e, em outro terreno, a aspirina, são exemplos de invenções tecnológicas não originárias, mas subsidiárias, no sentido de que se limitam a potenciar a satisfação de demandas sociais preexistentes. As invenções originárias, pelo contrário, se bem podem ter seu ponto de partida em propósitos concretos de alguns indivíduos e grupos, tendem a se desvincular destes rapidamente, e impor sua própria dinâmica expansiva, forçando uma renovação profunda na própria estrutura das demandas sociais" (NAVARRO, 2002).

${ }^{4}$ Isto por sua vez faz com que os próprios sensores não utilizados (como o olfato, o tato, etc.), e as informações geradas por eles, se deteriorem e atrofiem em favor do desenvolvimento do cérebro e do "pensamento". 
originalmente surge quase como um recurso mnemônico, ganha então um novo papel, o de criar a trama, amarrar os fatos ${ }^{5}$ e estabelecer o contexto no qual eles podem se estabelecer.

A escrita e a tecnologia de imprensa favoreceram uma leitura linear, predeterminada pelo autor. Um livro ou um texto para ser compreendido, em princípio, deve ser lido do início ao fim, palavra por palavra, parágrafo por parágrafo e página por página uma após outras. Quando alguém lê algo, a predisposição inicial é de entender o que o autor quer dizer. Está subentendido que a formação de um ponto de vista próprio, em princípio, só deveria ocorrer, ou não, no momento posterior à leitura global.

O texto, de uma certa maneira, é uma extensão da fala e reflete algumas de suas características. A mais importante delas é a organização das informações no tempo e no espaço, a partir de um ponto de vista determinado: do autor, do personagem ou da situação; em outras palavras, a partir de um determinado sujeito. Ao compor uma narrativa são construídos objetos e são criadas relações determinadas entre eles. É estabelecido um sistema de parâmetros espaciais e temporais em que os diferentes objetos, fatos e episódios observados se apresentam e estão articulados. Esta articulação não é aleatória, mas se dá a partir de determinado ponto de vista e ela viabiliza a sua "representação". Este encadeamento só é possível a partir dos parâmetros (e no interior) desse ponto de vista. ${ }^{6}$ A narrativa articula um ponto de vista (ou, dito de outra forma, ela constitui um sujeito) construindo um contexto, isto é, um referencial no tempo e no espaço dentro do qual uma intenção pode ser explicitada e entendida.

As tecnologias de escrita e impressão consolidaram esses modelos narrativos seqüenciais e com eles uma série de características que se constituíram no processo cognitivo de nossa espécie. ${ }^{7} \mathrm{~A}$ organização da informação em blocos estruturados por um determinado ponto de vista e pela narrativa que a estrutura e representa, origina uma separação de papéis entre os diferentes agentes da comunicação dividindo-os em autor e leitor (professor e aluno no caso da educação), constituindo um processo unidirecional, um fluxo em um único sentido a cada momento viabilizado através de um sistema de interrupções e permissões que, por sua vez, traz consigo uma relação hierárquica. Este tipo de relação, por sua vez, exige a legitimação do que está sendo

\footnotetext{
5 A linearidade representada por "começo", "meio" e "fim" como noção de totalidade, foi preconizada por Aristóteles: "um todo é aquele que tem princípio, meio e fim. Um princípio é aquele que em si não é, necessariamente precedido por outra coisa e que naturalmente tem algo depois. Um fim é aquele que naturalmente vem na confirmação de outra coisa, como sua conseqüência necessária e habitual; um meio é aquilo que por natureza está depois de algo e que tem algo depois..." (ARISTÓTELES apud BAIRON, 2000).

${ }^{6}$ De uma certa maneira eles são exclusivos daquele sujeito, num momento e lugar determinado. Quando o contexto, ao se afastar se "relaxa", o leitor começa a reconstruir o contexto a partir de seu ponto de vista e então temos a manifestação de outro sujeito. Um processo cognitivo deste tipo, evidentemente torna a interação precária.

${ }^{7}$ Carles Bellver Torlà, fala que os pensamentos "estão escritos deste modo (seqüencial e com um fio condutor) e é assim que se compreende o que dizem. Se os lemos de outra maneira, por exemplo, saltando de um fragmento a outro para frente e para trás, o mais provável é que captemos somente parte do sentido e, no melhor dos casos, apenas sob um determinado ponto de vista. No entanto, a leitura fragmentária, inclusive aleatória, é uma prática corrente não só do leitor acidental, mas também e, sobretudo, do 'connaisseur' que já sabe de antemão o que busca no texto. Os avanços sucessivos da tecnologia do livro, por exemplo, têm como objetivo possibilitar ao leitor ir diretamente aonde quer, ao capítulo ou à passagem do texto que fala do tema que lhe interessa, ou a outros textos vinculados com aquele. São modos de leitura habituais e muitas vezes indispensáveis, ainda que rudimentares. Uma referência a outro artigo em uma página de uma enciclopédia nos exige voltar a buscar, talvez, em outro volume. Do mesmo modo, uma nota de pé de página nos obrigará a voltar à biblioteca ou à livraria, e pode ser que tenhamos que esperar dias ou meses para receber o outro texto (TORLÁ, 2004)".
} 
transmitido através de um conjunto de $\operatorname{artifícios~}^{8}$ que facilitam a aceitação de pontos de vista estranhos à experiência do leitor (ou do aluno no caso da educação).

Por outro lado, ao trabalhar a informação apenas como relações estáveis, estabelecidas por uma estrutura determinada (em uma narrativa), a escrita possibilita a decomposição e recomposição de suas partes através da análise. Através de um contexto simbólico comum são criadas as condições de surgimento de um processo de manipulação lógica de símbolos que poderíamos chamar de "inteligência" ou de "pensamento". Apesar de não ser possível ao leitor se colocar sob o mesmo ponto de vista do autor em termos absolutos, isto acontece em termos relativos ao ser construído um quadro referencial comum no qual se viabilizaria uma espécie de transmissão e de passagem da informação.

Apesar da interatividade precária, estes mecanismos permitem a organização da espécie humana e ampliam sua capacidade de intervir na natureza através da criação de cadeias causais. A transmissão de experiências ocorre através de um fluxo de pacotes fechados (informação/educação/instrução/orientação) que, percorrendo relações hierárquicas, articulam múltiplas pessoas em processos de dimensões razoáveis. ${ }^{9}$

O resultado disto é o desenvolvimento em nossa espécie de um dispositivo cognitivo que se fundamenta e apóia em uma ordenação do texto literário (a fila indiana de caracteres) e em uma hierarquia (organização de capítulos, parágrafos, etc.) que "favorece uma leitura analítica e discursiva, assim como um modo de aprendizagem e conhecimento mais 'de cima para baixo' do que interativo e participativo" (BAZIN, 2000).

A chamada educação formal é expressão desta ordem mais ampla que definimos como Ordem do Livro. Ela guarda grande sintonia com as tecnologias de informação, comunicação e educação (a imprensa, o livro e a sala de aula) que lhe dá base e que estabelece um determinado tipo de relações específicas entre os agentes.

As práticas educativas criadas e estruturadas a partir da escrita e da cultura do livro, trabalham com um conceito de informação concebido como a representação de relações determinadas e imutáveis. A comunicação é vista como um processo de transmissão de informações, e a educação entendida como um processo de introdução de algo exterior, colocado no educando de fora para dentro.

Este tipo de educação reflete as restrições de um tipo de tecnologia capaz de operar apenas com um número limitado de informações. Apesar de as informações existirem como possibilidades infinitas por sua própria natureza, devido às técnicas utilizadas e às precárias possibilidades de processamento, elas foram organizadas e estruturadas em sistemas estanques de número limitado de elementos (um livro, uma biblioteca, um coletivo restrito de alunos e professores, etc.). Nestes limites restritos é possível descobrir relações estáveis e estabelecer a representação de uma totalidade.

\footnotetext{
${ }^{8}$ Poderíamos exemplificar citando a "autoridade" atribuída ao professor, os sistemas de aprovação, sistemas disciplinares, entre outros, como mecanismos que "facilitariam" a transmissão da "informação" do professor para o aluno.

${ }^{9}$ Não é esta a natureza do processo industrial?
} 
Este modo de organizar a informação, e a sua capacidade limitada de transporte e deslocamento, ${ }^{10}$ tem uma conseqüência inequívoca: a separação entre autor e leitor, emissor e receptor, educador e educando, obscurecendo o processo de interação entre esses diferentes agentes e criando a impressão de que o processo de comunicação e educação se desenvolveria em um único sentido. As relações sociais hierarquizadas, no início apoiadas em mecanismos coercitivos e repressivos (como ajoelhar no milho e ameaçar com vara de marmelo, regulamentos, sistemas de castigo e premiação, etc.) e mais tarde apoiadas em hegemonias ideológicas (autoridade da "experiência" e da "sapiência", sistemas de aferição de conhecimento, etc.), reproduzem esta percepção, produzindo e reproduzindo cotidianamente o mesmo tipo de relações, hierárquicas e assimétricas.

As características deste tipo de processamento de informações e de produção de conhecimento, assim como sua tecnologia e organização, levam, ainda, a que a educação seja concebida e organizada como algo separado do processo produtivo e da vida corrente; levam a que o processo de conhecimento seja algo separado da práxis social, especializado, e isolado no espaço da escola. A educação é vista como transmissão de conhecimento dos que sabem (os professores, os autores, etc.) para os que não sabem (o estudante e o leitor).

Os objetos que seriam transmitidos são os chamados conteúdos. A escola é pensada como um espaço e instrumento para essa transmissão, onde o professor é o agente ativo e as tecnologias procuram favorecer sua ação. A ordenação dos móveis na sala, voltados para o professor; o giz e o quadro-negro, o retro-projetor, a biblioteca, a administração de apoio, os supervisores, etc., tudo visa instrumentar a ação do professor e legitimar sua hegemonia. É ele que manipula a tecnologia, basicamente, para facilitar sua tarefa de introduzir o conhecimento no aluno "de fora para dentro".

A educação organizada desta maneira tem eficiência em sistemas simples (isto é, com número de elementos finito) e cumpre um papel produtivo dentro de determinados limites reduzidos de complexidade. Nestas condições ela serve como "disciplinadora", serve para constituição de hegemonias, serve para formar e instruir mão de obra para tarefas repetitivas.

Os problemas surgem quando as relações sociais e de produção se tornam mais complexas; quando se acelera a velocidade de inovação e se aprofunda a dinâmica de organização, desorganização e transformação destas relações. Podemos perceber intuitivamente que entramos em uma situação crítica, por exemplo, quando temos um processo de formação profissional que se propõe "formar o estudante para o resto da vida", mas os fundamentos da prática e ação do profissional mudam radicalmente no curso de sua vida. Isto ocorre, às vezes, antes mesmo que ele chegue ao mercado de trabalho.

Para reduzir este problema passou-se a desenvolver políticas chamadas de "educação permanente", mas como a tecnologia de educação permanecia a mesma, exigindo uma separação do processo produtivo (para reunir no tempo e no espaço os diversos educandos), a formação permanente ganhou a forma de pequenos pacotes, em períodos intercalados de atividade produtiva e educativa (cursos pequenos de um ano, às vezes de um semestre ou um mês, às vezes mesmo de alguns dias).

Outro problema das tecnologias educacionais da Ordem do Livro é a dificuldade de "personalização". Para que o processo educativo se viabilize economicamente, ele precisa reunir

\footnotetext{
${ }^{10}$ Limitadas quanto ao volume e velocidade de emissão, transmissão e assimilação pelas características das tecnologias utilizadas.
} 
um certo número mínimo de alunos (e, portanto necessita buscar um mínimo denominador comum entre eles). É necessária ainda a organização de um processo "industrial” de educação, com currículos, metodologias, pedagogias, cronogramas, etc., construídos à revelia do aluno.

Para responder às constantes e rápidas transformações, de algumas décadas para cá, ainda no limite da Ordem do Livro, a educação foi obrigada a se renovar pensando métodos pedagógicos e tecnológicos que não priorizam a transmissão de informações e que incorporam interatividade no processo educativo como é o caso, por exemplo, das teorias construtivistas. Mas, devido às restrições criadas pelas tecnologias utilizadas, a prática educativa era obrigada a manter suas características fundamentais (teoria separada da prática, isolamento espacial, atividades basicamente síncronas, hegemonia e controle quase absoluto do processo educativo por parte do professor, etc.). ${ }^{11}$

A incorporação da informática à educação, ${ }^{12}$ em nada modificou este processo. Porém o surgimento e consolidação da Internet (ao criar um sistema capaz de tornar universais os registros e o acesso ao sistema, ao estabelecer a comunicação em tempo real, ao desconsiderar parâmetros de espaço e tempo, ao promover uma interatividade exacerbada e ao viabilizar o processamento de informações em número infinito), criou uma série de problemas novos para a dinâmica educativa tradicional, ao mesmo tempo em que possibilitou (e em um certo sentido passou a exigir) novos tipos de práticas cognitivas.

\section{A ordem da web}

A diferença fundamental entre a Ordem do Livro e a Ordem da Web é que a primeira é expressão de um sistema capaz apenas de trabalhar com um número finito de elementos, enquanto a segunda viabiliza o processamento de um número infinito. É importante que se esclareça que entre os dois sistemas a diferença fundamental não é quantitativa, numérica. A diferença básica entre eles é que o primeiro trabalha com as informações separadas em compartimentos estanques $^{13}$ (em pacotes de número finito de elementos), enquanto o segundo viabiliza o estabelecimento de relação de qualquer tipo, entre todos os tipos de informação.

\footnotetext{
${ }^{11}$ Podemos observar um contraponto na educação não-formal como a apresentada na pedagogia de Paulo Freire ou em atividades massivas de educação como a Cruzada Nacional de Alfabetização da Nicarágua (SANTOS, 1990), que em outro tipo de ambiente mostram suas potencialidades. Nestas atividades educativas se restabelece a relação entre educação e prática produtiva, é superada a hierarquia entre professor (este leigo) e o aluno (com sua experiência de vida), e a educação é concebida como um processo de geração do novo.

${ }^{12}$ A "informática educativa" é o primeiro estágio deste processo de introdução da informática na prática educativa. Ver a apresentação do livro Professores e aprendizes na web (LUCENA; FUKS; SANTOS, 2000). O que marca este período é a visão de que esta introdução se daria para substituir práticas repetitivas (e não para produzir novas potencialidades), como em geral era vista a própria informática nesta época (final dos anos setenta e anos oitenta).

${ }^{13}$ Se imaginarmos a hipótese (absurda desde logo) de aumento da produção de informações sem incremento da interconexão, teríamos uma situação de multiplicação de sistemas finitos e especializados, onde as formulações, métodos, técnicas e tecnologias tradicionais não seriam colocadas radicalmente em questão. O problema aparece com o aumento da interconectividade e conseqüente mobilidade e capacidade de estabelecer sempre e a todo o momento situações novas (que se estabelecem e se modificam continuamente e em grande velocidade), já que o paradigma das tecnologias anteriores tem como premissa uma situação que é dada e pretensamente estável (o mundo existe e está aí, cabe apenas descobri-lo). Se o que cabe é descobrir (a verdade) e descobrir-conhecer as relações que já estariam estabelecidas, o problema central é estabelecer uma linguagem e forma de expressão mais próxima
} 
Estabelecendo um formato universal, o digital no qual pode se expressar qualquer tipo de informação e, com a criação da Internet e seus protocolos universais viabilizando o estabelecimento de relações de qualquer coisa com qualquer outra, romperam-se definitivamente as comportas e surgiu um sistema capaz de processar um número infinito de informações.

Quais são as diferentes características destes dois tipos de sistemas?

Em um sistema de carência, ou com um número finito de informações (de "relações estabelecidas"), o problema central é obter e preservá-las: "a informação vale ouro". Conforme o volume cresce, porém, o problema se desloca para como localizá-la. Em ambos os casos o valor ainda está na informação, entendida como relação estabelecida, como unidade de saber, como expressão e representação da verdade. $\mathrm{O}$ valor ainda está naquilo que é chamado normalmente de conteúdo, que seria igual à informação. Em um sistema deste tipo a estrutura e os instrumentos para seu processamento são coisas exteriores à informação. O sistema deve ser capaz de organizá-la como forma de preservar, acessar e dispor dela. ${ }^{14}$

Em um sistema de abastança de informações, por outro lado, o problema se desloca para a relação potencial entre os elementos, o valor não está nos elementos em si e nas relações já estabelecidas, mas na infinidade de relações possíveis de serem estabelecidas (inventadas). Neste sentido o chamado conteúdo perde valor e o importante passa a ser a capacidade de descobrir e estabelecer relações sempre novas e de todo o tipo.

A informação passa então a se caracterizar pelo ato criativo gerado pela relação dos elementos. Informação, aqui, é igual à relação, é o potencial de geração do novo que se origina através do estabelecimento de novas relações. $\mathrm{O}$ seu valor está nesse potencial de gerar o novo. O que já foi gerado (o "conteúdo") tem seu valor reduzido, se transforma em commodity. Esta mudança subverte a pedagogia tradicional e traz profundas consequiências para a educação e seus agentes, pois ela se estruturava em função da "posse" e transmissão de conteúdos.

Do mesmo modo, com o fim do confinamento da informação em compartimentos estanques, e com as características específicas do novo sistema, são colocadas em questão todas as "divisões" criadas pela Ordem do Livro e pela "educação formal". Entre elas a divisão entre tempo de educação e tempo de trabalho, entre espaço educativo e espaço social, entre teoria e prática, entre professor e aluno, que são algumas das mais importantes destas divisões.

possível desta "realidade”, capaz de desnudá-la. Interfaces estáveis, com fluxos, relações estabelecidas, permissões e interrupções, e uma ordem claramente definida podem ser viáveis nesta situação. Esta maneira de proceder era eficiente e em situações particulares ainda é. Não podemos desconsiderar as aquisições das teorias e das tecnologias criadas até aqui, mas devemos entendê-las como uma resposta particular para situações particulares. Do mesmo modo, cabe ressaltar que, como caso particular (pelo seu grau de elaboração), essas teorias podem nos oferecer muitos elementos para a reflexão de um quadro teórico mais geral, tanto do ponto de vista dos métodos e racionalidades como pelas intuições que aparecem em diversos de seus estudos.

${ }^{14}$ Como vimos, o texto (oral ou escrito) foi um dos primeiros dispositivos capazes de cumprir este papel. O texto cria um nexo de relações entre os elementos e cumpre funções mnemônicas que viabilizam guardar e acessar a elas. A força do canto e do verso na literatura oral tem uma de suas razões neste tipo de necessidade. O texto escrito inicia o processo de criação de uma interface mais estável e a lógica torna relativa a importância da memória humana. Trata-se de criar uma ordem no texto como forma de organizar as informações, função que inicialmente é respondida por uma estrutura que combina a criação de classes com uma estrutura hierárquica e que mais tarde vai ser ampliada pela narrativa (que permite estabelecer relações estáveis de uma maneira um pouco mais ampla). 


\section{Os problemas da educação formal}

Afirmamos que as características das tecnologias, organização e forma de processamento de informações e de produção do conhecimento na Ordem do Livro levam a que a educação seja concebida e organizada em um tempo e espaço próprio, como algo separado do processo produtivo e da vida cotidiana.

Apesar de não nascer assim, já que nas relações entre mestre e aprendiz inexistia separação entre prática produtiva e prática educativa, pois ambas se realizavam no mesmo espaço (o espaço de produção), com o desenvolvimento da industria e a necessidade de formação de mão de obra em escala industrial, a educação começou a se especializar e se constituir em um aparato particular separado da vida cotidiana e da produção. O processo de conhecimento se separa então da práxis social. A escola se transforma no espaço da educação, isolado e especializado. O tempo da educação passa a ser mensurável, um tempo determinado na vida (a época de estudante), no ano (o período escolar), e no dia (o horário do curso com sua grade de disciplinas).

Nesta dinâmica, o tempo da educação é anterior e separado da ação, o que leva a que as questões oriundas de sua implementação só se coloquem posteriormente, após a "formação", e pressionados então pela urgência do resultado. A educação nesse ambiente ganha o caráter de uma prática "especializada". Especialização que se dá pela prática e ideologia dominantes (de produção em escala), mas também porque esta separação tem uma dimensão operacional (tecnológica): ela facilita a aceitação do que esta sendo ensinado e viabiliza o processo de introdução de algo de fora para dentro, ao criar e consolidar no interior do espaço educativo (a escola) uma hegemonia, correlação de forças e a supremacia definitiva da máquina administrativa (incluindo os professores) por sobre o estudante. É através deste movimento que a escola ganha também as características de um instrumento de dominação ideológica e de reprodução das relações de produção.

A escola, em pouco mais de um século de "aperfeiçoamentos", construiu uma série de instrumentos para assegurar esta hegemonia e "facilitar" a transmissão de conhecimentos através de um conjunto de mecanismos como o currículo, regulamentos, sistemas de aferição, suas "forças de ordem" (psicólogos, assistentes sociais, instrutores, etc...), assim como, também, através da própria organização do espaço escolar (cadeiras e mesas dirigidas para o quadro-negro e para o professor, etc.).

Desde a segunda metade do século passado, no entanto, a escola entrou em crise em sua relação com a sociedade visto a inoperância desses métodos em responder a novas necessidades colocadas. Isso levou, como já afirmamos, a que surgissem críticas e teorias que visam a uma renovação do processo educativo. ${ }^{15}$ Ocorre, no entanto, que estas iniciativas encontram uma

\footnotetext{
${ }^{15}$ Ignés Aguerrondo, por exemplo, afirma que o "ensino de hoje ainda tem as mesmas características do sistema que estava em vigor no século XIX. É preciso uma grande transformação na concepção de escola. Lamentavelmente, o que existe hoje é uma organização não do século passado, mas do retrasado. Tudo o que fazemos se insere num velho modelo. [...] A educação necessária hoje não é [...] mais a educação dos saberes, não é mais a escola que resolvia a demanda da sociedade ensinando 'coisas'. Hoje necessitamos uma educação que forme em competências, o que é muito mais complexo que os saberes. [...] A competência é um saber fazer, com saber e com consciência. Inclui saberes, porém inclui consciência do que se está fazendo. Faz referência a um conjunto de propriedades de cada um de nós que estão se modificando permanentemente. Necessitamos de outra escola porque já não se trata do saber que o professor entrega e o aluno recebe, mas de um processo em permanente modificação e que deve se submeter à prova de resolver problemas concretos. É outra escola que não é mais a escola em que tudo se resolve
} 
barreira na escola e na tecnologia e organização da educação formal, devido ao seu isolamento de outras práticas sociais no tempo e no espaço. E nesse quadro elas apenas conseguem aprofundar a crise.

As transformações do processo educativo só se viabilizam se assumirem um caráter bastante mais radical, em particular avançando na eliminação (ou pelo menos na redução) da separação e isolamento do espaço educativo em relação a outros espaços e práticas sociais, na redução da hierarquia e distância entre professor e aluno, entre pensamento e ação, entre teoria e prática.

As novas tecnologias e a Internet, ao se organizarem fora de parâmetros espaço-temporais, nos oferecem instrumentos para isto, cobrando-nos a necessidade de repensar as práticas educativas nas novas condições e a partir das novas lógicas que se estabelecem.

Apresentamos a seguir algumas das questões críticas nas atividades educativas e algumas das grandes tendências que começam a se explicitar.

\section{Algumas notas indicativas das mudanças que hão de vir}

\section{Relação professor e aluno}

Preocupados em cumprir com o que seria sua pretensa função de "transmissão de informações para o aluno" na época da Internet, não sem protestar, os professores vivem um verdadeiro calvário:

Em primeiro lugar o professor ganha um "concorrente", pois com a Internet e uma habilidosa pesquisa, os alunos rapidamente podem ter acesso a uma gama muito maior de informações do que as que ele poderia oferecer em suas aulas. Pior que isto, com uma boa pesquisa em questões de minutos o aluno pode conhecer pontos de vistas diferentes e contraditórios, o que facilita a formação de sua opinião, além de descobrir coisas que certamente o próprio professor desconhece, pois o conhecimento é ilimitado. Assim, o problema não se restringe à quantidade de informações, mas alcança a possibilidade do contraditório, pois o aluno passa a conhecer informações e opiniões que questionam as oferecidas pelo professor; informações justificadas, referenciadas, apoiadas em uma variedade imensa de autores e experiências. Isto significa que o professor precisa dar adeus à pretensão de ser uma "autoridade inconteste". Agora ele precisa aceitar que se torne relativa a "natural" credibilidade que antes gozavam seus pontos de vista; ele não estará protegido no interior da sala de aula e nos limites de abrangência de uma meia dúzia de livros que ele próprio indicara.

com o lápis e o papel - tampouco com o computador - mas uma escola em que se podem enfrentar problemas concretos, seja da vida diária ou em situações de trabalho que envolve incertezas e certa complexidade técnica. A grande diferença com respeito à escola tradicional é que a competência não provém somente da aprovação de um currículo senão da aplicação de conhecimentos em circunstâncias práticas. Os conhecimentos necessários para poder resolver problemas não podem ser transmitidos mecanicamente. É uma mescla de conhecimentos tecnológicos prévios e de experiência que se consegue com a prática, muitas vezes nos locais de trabalho, e me pergunto porquê não, na experiência da escola" (http://www.utdt.edu/eduforum/ensayo1.htm). 
Em segundo lugar, e em parte como decorrência do anterior, o professor perde um de seus instrumentos fundamentais de controle sobre o processo educativo: os sistemas de aferição de aprendizado. Se o trabalho livre de pesquisa do aluno em muitos lugares já se afirmou com a crítica às provas em sala de aula, que aferiam principalmente a capacidade de memorização (o que com os potentes instrumentos que temos hoje, deixa de ser uma virtude significativa), como saber, agora, se aquele trabalho apresentado pelo aluno não é uma "mera" colagem ${ }^{16}$ de artigos encontrados em alguns sites a partir do Google?

Em terceiro lugar o professor perde o controle absoluto que tinha em relação à tecnologia de educação que praticamente ficava sob o seu controle. Agora ele comparte esta tecnologia com o aluno. E menos "viciados" pelas tecnologias e práticas intelectuais anteriores, os alunos tendem a dominá-las mais facilmente do que os professores.

Quando estamos construindo uma nova cultura, somos como imigrantes recém-chegados em uma terra estrangeira. Tradicionalmente, no processo de imigração, as crianças aprendem a língua, os hábitos e os códigos do novo mundo primeiro. Elas é que ajudam os pais na exploração do que para eles é terra incógnita e para as crianças já é seu ambiente.

Esta hipótese foi apresentada por Douglas Rushkoff (1997) no livro Playing the future. No caderno Mais, da Folha de São Paulo, Contardo Calligaris comenta o livro e pergunta:

E se nossas indignações não passam de lamentos de um mundo que já era? Os adolescentes nos parecem sem rumo? Mas o mundo não parece também sem rumo? Não será o caso de pensar que suas condutas estão inventando modos possíveis de viver neste mundo sem rumo?". Ruhkoff [...] "compara os comportamentos não-lineares dos adolescentes com o surgimento de modelos matemáticos não-lineares (os fractais) para descrever realidades caóticas e nelas encontrar recorrências. [...] O surfe, primeiro exemplo de Rushkoff, é de fato um esporte para o qual é vital a capacidade de entender e antever este elemento tão complexo e caótico que é uma onda. Do mesmo jeito, o skateboard verdadeiro, de rua, é um exercício de conquista do terreno urbano que resiste à linearidade dos percursos. Idem para o snowboard, que não consiste, à diferença do esqui, em traçar trajetórias elegantes na neve, mas em deixar de uma certa forma o elemento neve decidir as evoluções. Mais eloqüente ainda: a nova geração, treinada na leitura rápida da linguagem icônica e reduzida dos quadrinhos, talvez tenha elaborado, ou darwinianamente produzido, uma capacidade de leitura das imagens muito mais rápida do que a nossa. Por isso, ela não se satisfaria com a contemplação passiva de um programa de televisão, preferindo o ritmo da MTV ou então surfando na massa de informação proposta pela TV, de imagem a imagem. Ela não é pouco atenta ou incapaz de concentração, mas possuiria um tipo próprio de concentração que corresponde adequadamente à circulação de informação de nossos tempos. Enfim, a Internet [...] é de fato o lugar virtual aonde aos poucos vem se reconstituindo uma comunidade perdida e a globalização não é só um projeto econômico multinacional. [...] Por

\footnotetext{
${ }^{16}$ A capacidade de relacionar pedaços de texto (não é isto uma colagem?) é uma das grandes competências do futuro, porque ela mostra a capacidade de criar novas relações, caminhos transversos, alternativos às idéias já estabelecidas. Com as práticas que temos hoje, o que se estimula no aluno é aprender a escrever de maneiras novas as mesmas idéias estabelecidas e apresentadas pelo professor.
} 
isso mesmo, Rushkoff escolheu chamar os adolescentes (teenagers) de "screenagers" (de "screen", tela): os jovens da época da tela (da TV e do computador) (CALLIGARIS, 1996).

Rushkoff (1997) não inventou esse termo, "screenagers"', para corroborar uma opinião corrente sobre a preguiça dos jovens, mas para indicar que as mudanças do tempo "quase por evolução darwiniana talvez tenham produzido uma nova geração adaptada às mudanças tecnológicas".

Estes e outros fatos levam a uma modificação de correlação de forças entre professores e alunos, que subverte a hierarquia tradicional. Isto exige do professor a mudança de sua prática de ensino, obriga a que ele se recicle, o que muitas vezes é difícil porque não lhe é dado suporte, formação e recursos para fazê-lo.

A mudança precisa ser drástica. De mero transmissor de saberes o professor agora é obrigado a favorecer competências, a preparar o aluno para que ele próprio possa buscar as informações e os saberes que necessita. Isto exige práticas novas, novas dinâmicas e uma nova pedagogia...

\section{Espaço educativo e práticas sociais}

Por outro o lado, com essas novas tecnologias, a escola tende a perder o monopólio das práticas educativas, ou pelo menos, perde a hegemonia e exclusividade que tinha como espaço onde elas se realizam. Através de novas práticas educativas e alimentando-se das novas tecnologias de informação, em particular da Internet, a educação invadirá a vida, as moradias, as empresas, as organizações civis, fazendo com que a separação entre prática educativa e prática social se dissolva e se torne relativa.

Este processo vem se verificando nas últimas décadas, antes mesmo que a Internet se oferecesse como um espaço educativo universal. Neste período o espaço educativo vem se desdobrando e ficando cada vez mais complexo.

Até os anos 60 do século passado, a escola era basicamente a escola pública e, em muito menor quantidade, as escolas de ordens religiosas. A elas se somaram atividades educativas de ONGs e de organizações civis, cursos à distância e, principalmente, escolas privadas que abarcam hoje um complexo conjunto de atividades que vão da escola formal aos cursos de capacitação, instrução, reciclagem, especialização, etc.

A atividade educativa ganhou complexidade e atividades que não se relacionam apenas e diretamente com a educação formal passaram a ter cada vez mais importância. Um exemplo de atividade educativa não formal, favorecida por novos instrumentos, é a autoformação, viabilizada pelo aumento e diversificação dos serviços de informação e comunicação, das bibliotecas, publicações, livros, manuais, multimídias, etc... Este tipo de prática estará cada vez mais presente na educação em nossa sociedade futura. Além disto atividades educativas são desenvolvidas por organizações de massa, por organizações da sociedade civil, por grupos religiosos, por organizações profissionais, empresas, organizações patronais e por todo o tipo de organização. 
O aumento da complexidade da atividade humana e a aceleração do processo de inovação levaram a atividade educativa a desbordar a escola e a educação formal. Uma variedade de práticas que se desenvolveu em uma sociedade cada vez mais complexa estimulou um sem numero de produtos, técnicas, processos, metodologias e canais de formação e capacitação para operacionalizá-los. Os cursos de "especialização", de "instrução", os "cursos técnicos" e mais recentemente as "certificações", os MBAs, as atividades ligadas a recursos humanos nas empresas, entre outros, ofereceram respostas a este tipo de necessidade. Mas além disto, toda uma série de necessidades de formação técnica e instrumental se deslocou para as "bulas", para os manuais, para os roteiros sobre como usar, para os "Passo a Passo", serviços de suporte e mais recentemente as FAQs (Freqüentes Perguntas e Respostas) e as "Ajudas" de equipamentos eletrônicos que "ensinam" as pessoas como colocá-los em marcha e com eficiência. Existe uma série de instrumentos que se aprimoram e assumem funções educativas, permitindo a educação instrumental de uma diversidade de fazeres e o conhecimento de uma série de saberes em constante mutação.

Com esta observação procuramos expressar uma percepção de que a atividade educativa tende a ser cada vez mais ampla, diversificada e em processo de constante transformação. Não é mais possível restringir o processo educativo à educação formal. A educação tende a ocupar espaços cada vez mais importantes fora da escola, fora daquele que era o seu espaço exclusivo.

Isso nos leva a pensar que o processo de educação entendido como preparação para uma profissão (o "tempo de estudante"), isto é, como um processo separado no tempo e no espaço, perde sua viabilidade e principalmente sua pertinência. Esta deve ser uma questão prioritária pensada no processo educativo. A redução destas jornadas, assim como sua maior aproximação da vida cotidiana, devem ser pensadas para que a educação seja capaz de recuperar o seu vigor e cumprir seu papel. A estrutura escolar necessita hoje de uma maior relação com a sociedade como condição de sua sobrevivência. Ela precisa se oferecer como um espaço de troca, de suporte e de formação, aberto e em constante sincronia com as dinâmicas da sociedade, o que passou a ser viável com as novas tecnologias. A educação formal - e a escola - com o tempo será apenas um núcleo polarizador, uma espécie de órgão especializado de suporte, estimulador e irradiador de um conjunto de atividades educativas que se desdobrem por toda a sociedade.

As novas tecnologias de comunicação e a Internet se apresentarão como espaço privilegiado e universal de articulação das atividades educativas. Isto nos leva a heresia de dizer que ao contrário do que muitos pensam, ao pretender domesticar estas tecnologias no interior do espaço escolar, a Internet e os meios de comunicação e telecomunicação tendem a se tornar, eles sim, o espaço educativo universal e privilegiado da educação. A sala de aula se transformará em apenas um de seus suportes, uma de suas atividades, mesmo que continue a ter muita importância.

Uma nova estrutura com grande potencial educativo que deverá assumir cada vez mais importância deverão ser as comunidades virtuais. Estas comunidades são espaços de aprendizado, de reflexão e ação; um locus privilegiado para uma nova prática educativa, troca de experiências, coordenação de atividades, debates e pesquisas; oferecendo informações e referências em uma atividade de produção coletiva de conhecimento que favorece o desenvolvimento individual.

\section{Cognição individual e cognição social}


Um outro grande campo de modificação da prática educativa está ligado ao que se poderia chamar de práticas cognitivas individuais e sociais. Torna-se explicito o que antes acontecia de forma camuflada: não existe conhecimento individual que não seja gerado, desenvolvido, amadurecido, enfim, parido nos marcos de um processo de cognição social. As reflexões sobre estas questões não são novas. Já podemos encontrá-la, por exemplo, em Gramsci no conceito de intelectual orgânico.

Para garantir a apropriação privada do produto deste conhecimento, foram formuladas teorias de direitos autorais, ${ }^{17}$ e criadas relações de poder onde se superestima aquele que dá o "arremate", que faz a síntese e sistematiza esta prática coletiva. ${ }^{18}$

Mas com a Internet o caráter coletivo da produção de conhecimentos fica evidente. Aldo Barreto nos lembra que "o computador permite uma liberdade de lidar com o texto, livre das amarras da composição e da interpretação linear" (BARRETO, 2004). Com a Internet aparecem os "artefatos de informação abertos" que:

São objetos de informação que estão: ou em se fazendo ou que, apesar de acabados, podem ter seu conteúdo modificado continuamente devido a um sucessivo diálogo do gerador consigo mesmo e pela participação permitida e espontânea dos seus vários usuários-geradores. Aqui a informação se encontra em continua formação, por motivos da interatuação permitida pelo ciberespaço. [...] Este novo aspecto da informação trará certamente problemas para a determinação dos direitos de propriedade que está em nossa legislação como: 'são obras intelectuais protegidas as criações do espírito, expressas por qualquer meio ou fixadas em qualquer suporte'. A propriedade intelectual de uma informação que se encontra em se fazendo e em um suporte digital, com interatividade na sua construção e diversos geradores interatuando dependerá de se estabelecer, através de um código de convivência e trocas, uma condição de utilidade circunstancial para o usuário; seria, então, atribuída à informação um valor circunstancial de uso, de acordo com seu estado ou condição em determinado momento. Restará determinar no final de quem é a propriedade da coisa toda" (BARRETO, 2004).

O processo de construção coletiva do conhecimento na educação já foi ressaltado por Vygotsky (1987) descrevendo como, nas interações de um grupo, ocorre um processo de conhecimento coletivo no qual as diferentes experiências oferecem um rico material de aprendizado. Segundo ele é mais fácil para o estudante entender uma questão quando ela é apresentada por um igual, alguém que se situa em uma situação de proximidade e que tem experiências similares. Temos algo similar nas comunidades virtuais, verdadeiros espaços educativos, onde os diferentes

\footnotetext{
${ }^{17}$ Cabe ressaltar que não deixamos de reconhecer que o direito autoral responde a um problema econômico: o de garantir recursos para formação e investimentos necessários ao desenvolvimento do "autor". O que queremos ressaltar, sem usar aqui nenhum juízo de valor, é que o autor não existiria no caso em que não existissem experiências, práticas e massa crítica criadas pelas reflexões coletivas das quais pudesse partir e se apropriar.

${ }^{18}$ Teoricamente poderíamos dizer que o autor é apenas aquele que provoca uma "emergência”, isto é, estrutura no tempo e no espaço, um processo virtual, o conjunto de idéias e práticas, independentes de tempo e espaço, produzidas pelo e no coletivo.
} 
membros do grupo, mesmo que não intervenham, acompanham o processo de amadurecimento das idéias e das experiências trabalhadas.

As novas tecnologias oferecem um potente instrumento para favorecer este tipo de experimentação. Ao contrário do texto onde a narrativa assegura um determinado ponto de vista e sujeito, o texto eletrônico e em especial o hipertexto oferece um suporte para a interação

permitindo acomodar no seu interior diferentes sujeitos e pontos de vista. É claro que aqui será importante entender o hipertexto não como um texto desdobrado, o que seria só e apenas um pedaço de hipertexto. O habito de trabalhar com o texto nos leva a ver o hipertexto a sua imagem e semelhança: Como se fosse uma página onde existem links que se assemelham a notas de pé de página, indicações bibliográficas e outras referências; isto é um pedaço de hipertexto localizado no tempo e no espaço, onde e possível sobreviver uma única narrativa, um único sentido e relevância.

Mas o hipertexto e sua dinâmica só podem ser entendidos se o compreendemos como uma estrutura universal (como o conjunto dos textos que ele reúne), o que permite estabelecer relações além daquelas já estabelecidas pelos links, utilizando as dinâmicas de busca aleatória (sistemas de busca) e outros meios que surgirão e que sequer podemos imaginar quais serão. Permitindo que se criem relações novas e muitas vezes inusitadas, que produzem novas emergências e que constroem novos nexos em outros espaço e tempos...

Landow (1995), afirma que com o hipertexto experimentamos "um sistema que se pode descentrar e re-centrar até o infinito, em parte porque ele transforma qualquer documento que tenha mais de um nexo em um centro passageiro, em um diretório com que podemos nos orientar e decidir aonde ir em continuação". Os princípios de organização da informação e a hierarquia, deste modo, podem ser superados com o leitor (e do mesmo modo o estudante) escolhendo e constituindo-se em centro de sua investigação e experiência.

A redefinição dos papeis possibilitada pelo hipertexto na relação ensino-aprendizagem desloca o poder e a autoridade do professor para o aluno, na medida em que o sistema emissor-receptor é alterado. A possibilidade de construção e reconstrução do conhecimento deixa assim de ser um domínio de alguém que "detém o conhecimento".

\section{Educação em massa e personalização}

“O que você vai ser quando crescer?", é uma pergunta que nos fizeram e nós mesmos fizemos, muitas vezes em nossas infâncias. Esta pergunta reflete o ponto de vista da educação tradicional. Voltada para as necessidades da sociedade industrial ela educava alguém para cumprir uma função pré-determinada por este processo industrial. As funções estavam predeterminadas pelas profissões: você poderia ser um mecânico, um tecelão, um engenheiro, um contador, etc. Visando o perfil a ser formado era organizada uma série de atividades de processamento de informação, de rotinas e práticas que preparavam o aluno para realizar certas atividades predeterminadas.

Com isso o ensino ganhou características de produção em escala. Natural a importância que ganha o currículo escolar neste tipo de lógica. Ele procura assegurar as características que seriam fundamentais para aquela profissão e garantir um conjunto de atividades que deveriam ser 
cumpridas independentemente das características particulares dos estudantes ao qual elas se aplicariam. Os processos de aferição de conhecimento, também independente das características particulares do estudante, procuravam assegurar o cumprimento deste currículo.

Este tipo de abordagem traz dois tipos de problemas:

1) Quando o aluno no meio do curso ou ao terminá-lo descobre que não era bem aquela sua vocação, ele é obrigado a optar entre continuar mesmo que descontente, ou mudar de carreira e começar tudo de novo (o que freqüentemente acontece);

2) Quando a sociedade ganha complexidade, as carreiras se tornam incapazes de responder a novas necessidades, diferentes das que se colocavam anteriormente (cursos de especialização procuram enfrentar esta situação).

O problema se amplia quando a sociedade se modifica em um processo acelerado como ocorre hoje em dia, e quando, terminando um prolongado processo de formação, o estudante descobre um mercado de trabalho completamente diferente de quando começou a estudar, exigindo novas competências e valorizando-as de maneira sempre cambiante.

O mercado de trabalho exige hoje um tipo de educação nova não centrada em currículos, mas no educando. Só este tipo de dinâmica permitirá que o estudante desenvolva sua formação em um processo de constantes adaptações, usando suas potencialidades particulares e adaptando-as às possibilidades que se colocam a cada momento.

O processo de educação só poderá ser entendido como um processo permanente visando não apenas formar para uma atividade profissional, mas para desenvolver plenamente potencialidades e melhor viver a vida. Neste sentido colocar-se-á, cada vez mais, para cada um de nós, a necessidade de estabelecer uma "política de educação" própria, estabelecendo objetivos; reunindo e mobilizando um conjunto de instrumentos que a sociedade coloca a nossa disposição nos espaços da educação formal, mas também na Internet e em diversos outros espaços; usando todos os recursos possíveis; estudando nossa aplicação de forças e recursos, estabelecendo nossas próprias rotinas e métodos de autoformação.

\section{Referências}

BARION, S. Hipermídia, psicanálise e história da cultura. Caxias do Sul: Educs; São Paulo: Mackenzie, 2000.

BARRETO, A. O Minotauro chora. DataGramaZero: revista de Ciência da Informação. Rio de Janeiro: Iasi, 2004

Uma cerimônia com ritos próprios. DataGramaZero: revista de Ciência da Informação, Rio de Janeiro: Iasi, 2004.

BAZIN, P. Bibliothèques publiques et revolution numérique. In: CONFERÊNCIA INTERNACIONAL BIBLIOTECAS PÚBLICAS: INVENTANDO O FUTURO, 2000, Lisboa. Anais eletrônicos... Lisboa: Instituto Português do Livro e das Bibliotecas, 2000. Disponível em: <http://www.iplb.pt/pls/diplb/!get_page?xid=930>. Acesso em: 10 jan. 2005. 
CALligARIS, C. Tocando o futuro: "Screenagers" encaram o caos. Folha de São Paulo, São Paulo, 6 out. 1996.

CASAS, L. A. A. Contribuições para a modelagem de um ambiente inteligente de educação baseado em realidade virtual. Tese (Doutorado em Engenharia de Produção) - Programa de PósGraduação em Engenharia de Produção, Universidade Federal de Santa Catarina, 1999.

DERTOUZOS, M. O que será... São Paulo: Companhia das Letras. 1998.

KUHN, T S. A estrutura das revoluções científicas. São Paulo: Perspectiva, 1975.

LANDOW, G. Hipertexto: la convergencia de la teoría crítica contemporánea y la tecnología. Barcelona: Paidós, 1995.

LÉVY, P. As tecnologias de inteligência: o futuro do pensamento na era da informática. Rio de Janeiro: Ed. 34, 1993.

LUCENA, C.; FUKS, H.; SANTOS, N. Professores e aprendizes na web: a educação na era da Internet. Rio de Janeiro: Clube do Futuro, 2000.

MATURANA H.; VARELA F. El arbol del conocimiento. Santiago de Chile: Programa de Comunicación Transcultural, OEA, 1984.

MORIN, E. Epistemologia da Complexidade. In: SCHNITMAN, Dora Fried (Org.). Novos paradigmas, cultura e subjetividade. Porto Alegre: Artes Médicas Sul, 1994. p. 274-289.

NASBITT, J. Paradoxo Global. Rio de Janeiro: Campus, 1994.

NAVARRO, P. Información, comunicación, conocimiento y agencia en la era de la socialidad artificial. In: BLANCO, J. M. G.; NAVARRO, P. Mas allá de la modernidad?: las dimensiones de la información, la comunicación y las nuevas tecnologías. Madrid: Centro de Investigaciones Sociológicas, 2002.

NEGROPONTE, N. A vida digital. São Paulo: Companhia das Letras, 1995.

RUSHKOFF, D. Um jogo chamado futuro: como a cultura dos garotos pode nos ensinar a sobreviver na Era do Caos. Rio de Janeiro: Revan, 1997.

SANTOS, N. B. A informação e o paradigma holográfico: a utopia de Vannevar Bush. DataGramaZero: revista de Ciência da Informação, [S. 1.], v. 3. n. 6, dez. 2002. Disponível em: <http://www.dgz.org.br/dez02/Art_06.htm>. Acesso em: 10 jan. 2005.

. E também lhes ensine a ler: a experiência da Cruzada Nacional de Alfabetização da Nicarágua. Rio de Janeiro: Ayuri Editorial, 1987.

TOFFLER, A. O choque do futuro. Rio de Janeiro: Record. 1970.

TORLÀ, C. B. Leer y escribir después de los libros. Disponível em: <http://nti.uji.es/docs/nti/net/despues/index.html>. Acesso em: 29 nov. 2004.

VYGOTSKY, L.S. Mind in society. Cambridge, MA: Harvard University Press, 1978. 
_. Pensamento e linguagem. São Paulo: Martins Fontes, 1987. 